language markets. Other presentations discussed ways in which "new methodologies" such as corpus-based translation studies can be applied to translated children's literature (Michal Borondo), the role of copyeditors in the making of a translated children's book (Marija Zlatnar Moe \& Tanja Žigon), censorship of political commentary in translated children's books (Laura Leden), etc. Other topics included translating the dual address, fairy tales, or classics such as Alice in Wonderland.

On the third day, the participants travelled to the beautiful Grauwzusters Cloister in Antwerp, where they were greeted with a keynote lecture by Cecilia Alvstad (University of Oslo) on children's literature and global concerns that looked into translations of children's books on current global issues such as the refugee crisis. The five panels that followed included fascinating accounts of Russian adaptations of classic children's books such as Pinocchio (Natalia Kaloh Vid), which became the Russian Buratino, or Harry Potter (Pieter Boulogne), which inspired the character of the witch Tanya Grotter, the surprising reception of Edmondo de Amicis's works in North Korea (Theresa Hyun), and pre- and post-apartheid translation flows of children's literature in Afrikaans (Anzette Williams), as well as topics such as relay translations, translating the canon, and multimodal translation.

The Conference closed with an engaging keynote lecture by Gillian Lathey (University of Roehampton, London) entitled "Only English Books': The Mediation of Translated Children's Literature in a Resistant Economy", which brought the programme full circle and back to one of the first panel discussions about the "impenetrable British market". The dominance of English children's literature and the English market's simultaneous resistance to translation was once again confirmed and seemed to run like a common thread through the Conference, which manifested itself not only in reflections during the panels, but also in the choice of the case studies presented, which very often dealt with the translation of English children's literature.

Theresia Feldmann

\title{
Međunarodna konferencija „Literature, Translation, and Mediation by and for Children: Gender, Diversity, and Stereotype“
}

Centro Residenziale Universitario di Bertinoro (CEUB), Italija, 25. - 27. listopada 2017.

DOI: 10.21066/carcl.libri.2017-06(02).0019

Rezidencijalni sveučilišni centar u Bertinoru (Centro Residenziale Universitario di Bertinoro, CEUB) nalazi se u živopisnome srednjovjekovnome gradiću Bertinoru, okruženome vinorodnim brežuljcima talijanske pokrajine Emilije i Romanje, a udaljenome tridesetak kilometara od jadranske obale. U tome poviješću pregnantnome okruženju, od 25. do 27. listopada 2017. godine, održana je trodnevna konferencija „Literature, Translation, and Mediation by and for Children: Gender, Diversity, and Stereotype“ u organizaciji Centra MeTra; Forlì (Centro di Studi interdisciplinari sulla Mediazione e la Traduzione a opera di e per Ragazze/i). Centar je dio Odjela za prevođenje (Dipartimento Interpretazione e Traduzione) Sveučilišta u Bologni. Bavi se istraživanjem prevođenja i jezičnoga posredovanja književnosti za djecu i mladež, a njegov su važan, iako ne i jedini aspekt istraživanja rodni studiji. MeTra je međunarodni referentni centar koji nudi bibliografske i 
teorijske resurse te promiče međunarodne inicijative i suradnju s drugim sličnim centrima i udrugama.

Konferencija je okupila više od 50 izlagača iz 13 zemalja iz raznih dijelova svijeta (Italije, Nizozemske, Španjolske, Portugala, Francuske, Ujedinjenoga Kraljevstva, Irske, Poljske, Njemačke, Hrvatske, Kanade, Čilea, SAD-a) te osamdesetak sudionika. Program se sastojao od dvaju plenarnih predavanja i rada u sesijama. Zbog paralelnoga održavanja dviju, a ponekad i triju sesija, koje su nudile velik broj zanimljivih, aktualnih, pa i kontroverznih tema, nije bilo moguće popratiti sve, pa izdvajam nekoliko najzanimljivijih u kojima sam sudjelovala.

Tematski podijeljena u nekoliko područja konferencija je započela temom kulturnih identiteta i raznolikosti te rodnih identiteta. Nakon plenarnoga predavanja Jemine Napier sa Sveučilišta Heriot-Watt u Škotskoj na temu dječjega jezičnoga posredovanja u manjinskim zajednicama, u kojemu je izlagačica govorila o jezičnome posredovanju u obiteljima u kojima su roditelji gluhi ili imaju problema sa sluhom, posebno intrigantna bila su izlaganja o romskim i sintskim dječjim likovima u nizozemskoj književnosti za djecu i mladež (Sara Van den Bossche) te o prikazu LGBTQ-obitelji u talijanskim prijevodima američke hit-slikovnice And Tango Makes Three (Dalila Forni).

Drugi dan konferencije bio je u znaku dječjega jezičnoga posredovanja, prevođenja dječjih svjetova i prevođenja za djecu te rodnih identiteta i rodnih stereotipa u prijevodima književnosti za mladež. Izdvajam raspravu o ulozi prevoditelja dječje književnosti koju je potaknulo izlaganje talijanske prevoditeljice Mirelle Piacentini („Il traduttore di libri per bambini e ragazzi tra stereotipi e luoghi comuni“), iz koje se moglo zaključiti da se prevoditelji dječje književnosti bore sa sličnim predrasudama i nerazumijevanjem bez obzira na to u kojoj zemlji žive i rade. Nakon toga uslijedila su dva izlaganja o rodnim stereotipima: u prijevodima priča braće Grimm na španjolski (Rocío García Jiménez) i prijevodima japanske dječje književnosti na talijanski jezik (Maria Elena Tisi). Heidrun Gerzymisch, eminentna njemačka stručnjakinja iz područja translatologije, govorila je o prevođenju univerzalija u dječjoj književnosti. Drugi je dan zaokružen plenarnim predavanjem B. J. Epstein sa Sveučilišta u East Angliji u Ujedinjenome Kraljevstvu, koje se bavilo prevođenjem queer dječje književnosti.

Treći, ujedno i zadnji dan konferencije, bio je podijeljen u tri paralelne sesije posvećene trima temama: izazovima u dječjoj književnosti, prevođenju i adaptacijama te rodnim stereotipima.

O prevođenju talijanske dječje književnosti na hrvatski jezik u 20. stoljeću i položaju talijanske dječje književnosti u hrvatskoj osnovnoškolskoj lektiri govorila je Marija Andraka, a Smiljana Narančić Kovač tematizirala je promijenjene dječje svjetove u prijevodima Carrollove Alice i Hlapića Ivane Brlić-Mažuranić. Ana Martín-Macho Harrison izložila je zanimljiv rad o talijanskim i španjolskim prijevodima poznate slikovnice o Gruffalu (koji je kod nas preveden kao Grubzon).

Konferencija je otvorila mnoge teme, pružila mogućnosti za razmjene znanja i iskustava te je pokazala da dinamično područje prevođenja dječje književnosti nudi prostor za nova istraživanja o kojima će se raspravljati na konferencijama koje će, nadamo se, uslijediti. 